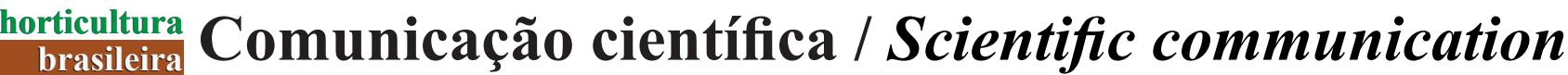

ALEXANDRE MAV; DUARTE LML; RAMOS AF; HARAKAVA R. 2015. Identification and molecular characterization of Carnation mottle virus Brazilian isolates from carnation. Horticultura Brasileira 33: 257-260. DOI - http://dx.doi.org/10.1590/S0102-053620150000200019

\section{Identification and molecular characterization of Carnation mottle virus Brazilian isolates from carnation}

\author{
Maria AV Alexandre; Ligia ML Duarte; Alyne F Ramos; Ricardo Harakava \\ Instituto Biológico, Av. Cons. Rodrigues Alves 1252, 04014-002 São Paulo-SP; alexand@biologico.sp.gov.br; duarte@biologico.sp.gov. \\ br; lyramosbio@hotmail.com; harakava@biologico.sp.gov.br
}

\begin{abstract}
Carnation mottle virus (CarMV), associated with carnation plants showing or not symptoms, was identified by host range, serology and molecular analysis of the coat protein gene. Seven samples were assayed by biological and serological tests. Two of them, one from São Paulo and another from Minas Gerais states, Brazil, which presented higher absorbance values in DAS-ELISA, were selected for molecular studies. Foliar samples were submitted to total RNA extraction, RT-PCR with specific primers, and amplicons obtained were sequenced. Phylogenetic analyses were carried out using the PAUP program after determining the nucleotide substitution model. The identity percentages between Brazilian sequences were 99\%. When sequences of CP carnation isolates from other countries were compared, the identity ranged from $96-99 \%$. CarMV isolates from São Paulo and Minas Gerais states are the first sequences obtained in Brazil, and analysis showed that they belong to the PK group and showed only two amino acids changes at positions 61 and 260. The virus presents a high genetic stability and it is readily mechanically transmitted from infected to healthy plants. This is the first report of CarMV in Minas Gerais state, of CP nucleotide sequences from Brazilian CarMV isolates, as well as molecular phylogenetic analysis in Brazil.
\end{abstract}

Keywords: Dianthus caryophyllus, Carmovirus, phylogenetic analysis.

\section{RESUMO}

Identificação e caracterização molecular de isolados brasileiros de Carnation mottle virus em craveiros

Carnation mottle virus (CarMV) foi identificado em craveiros com e sem sintomas, pelo círculo de hospedeiras, teste sorológico e analise molecular da capa proteica do genoma viral. Sete amostras foram avaliadas por testes biológicos e sorológicos. Duas delas, uma proveniente de São Paulo e outra de Minas Gerais, que apresentaram os maiores valores de absorbância em DAS-ELISA, foram selecionadas para estudo molecular. Folhas foram submetidas à extração de RNA total, RT-PCR com iniciadores específicos, e os amplicons sequenciados. As analises filogenéticas foram realizadas com o programa PAUP após determinar o modelo de substituição. A identidade entre as sequencias brasileiras foi $99 \%$. Quando sequências brasileiras foram comparadas com as de outros países, as identidades variaram de 96 a 99\%. Sequencias de isolados de SP e MG são as primeiras brasileiras do CarMV e, as análises mostraram que elas pertencem ao grupo PK e têm duas mudanças de aminoácidos nas posições $61 \mathrm{e}$ 260. O vírus apresenta alta estabilidade genética e é mecanicamente transmitido com facilidade de plantas infectadas para sadias. Este é o primeiro relato de CarMV em MG, de sequência de nucleotídeos da CP de isolados brasileiros de CarMV, bem como de análise filogenética molecular, no Brasil.

Palavras-chave: Dianthus caryophyllus, Carmovirus, análise filogenética.

(Recebido para publicação em 21 de julho de 2014; aceito em 19 de dezembro de 2014) (Received on July 21, 2014; accepted on December 19, 2014)

\begin{abstract}
A lthough Brazil is not a traditional exporter of flowers and ornamental plants, the professionalization involved in this segment has been increasing as to place the country among the world's largest flower producing countries (Junqueira \& Peetz, 2002). The cut flowers are one of the main sectors of the flower market, and among them stands out the carnation Dianthus caryophyllus (Caryophyllaceae). It is worth mentioning that in April 2012 one of the main flower producers in Brazil sold nearly 400,000 carnation stalks. In the state of Minas Gerais carnation is among the most cultivated cut flowers,
\end{abstract}

encompassing 12,629 ha (Landgraf \& Paiva, 2009).

D. caryophyllus originally from a vast region extending from southern Europe to India found favorable conditions for its cultivation in regions with warmer climate of Brazil (Souza \& Simão, 1981). D. caryophyllus has been grown since ancient times and several varieties were known in Europe before the XVII ${ }^{\text {th }}$ century. Breeding that led to the recurrent flowering hybrids started in France in 1840. Currently, several types of carnation are grown worldwide (Lisa, 1995).

Several viruses have been described infecting carnations, as Carnation mottle virus (Carmovirus), Carnation vein mottle virus (Potyvirus), Carnation etched ring virus (Caulimovirus), Carnation necrotic fleck virus (Closterovirus), Carnation cryptic virus (Alphacryptovirus), Carnation latent virus (Carlavirus) and Carnation ringspot virus (Dianthovirus) (Lisa 1995). However, in Brazil only CarMV has been reported so far in symptomless carnations (Caldari Junior et al., 1997).

The origin of CarMV is unknown. The virus was first detected in UK, into which it was probably introduced in commercial stocks of carnations and/ 
or pinks. It was described by Kassanis in 1955 and currently widespread wherever carnations are growing (Brunt \& Martelli, 2008; Safari et al., 2009; Cevik et al., 2010).

CarMV is the type species of the Carmovirus genus, Tombusviridae family (ICTV 2013). The members are icosahedral virions, about $30 \mathrm{~nm}$ in diameter, containing a single-component positive-sense genome of about $4.0 \mathrm{Kbp}$ (Qu \& Morris, 2008). Furthermore, CarMV does not have a known vector and is not seedborne, although it is easily transmitted mechanically. CarMV infects especially species in the Caryophyllaceae, but it was found naturally infecting Begonia, Daphne (Brunt \& Martelli, 2008), Zanthedeschia (Chen et al., 2003), Opuntia ficus-indica (GenBank Accession n ${ }^{\circ}$ EF 584754 and EF 584755), Phalaenopsis (Zhen et al., 2011) and Eustoma grandiflorum (Chen et al., 2011).

This article deals with serological identification and molecular comparison between two Brazilian CarMV isolates from carnation and from other countries.

\section{MATERIAL AND METHODS}

Seven leaf samples of carnation, six from a flower shop in São Paulo (SP 14-19) and one from commercial crop in Senador Amaral (MG 1669) were examined. Extract of symptomatic and asymptomatic samples were obtained by grinding leaves in a mortar with $0.05 \mathrm{M}$ phosphate-buffered saline (PBS) pH 7.4 containing $0.5 \%$ sodium sulphide and mechanically inoculated, using a carborundum abrasive, on Chenopodium amaranticolor, C. quinoa, Dianthus barbatus "sweet william", D. caryophyllus and D. chinensis. Inoculated plants were maintained in an insect-proof greenhouse for up to 30 days to allow symptom development.

Each sample in triplicate was tested for CarMV using double antibody sandwich DAS-ELISA, as described by Clark \& Adams (1977). Capture antibody and alkaline phosphatase enzyme conjugated were purchased from AGDIA Inc (Indiana, USA), including positive and negative controls. Absorbance values were recorded using a Microplate Reader (Bio-Rad), 30-45 min after substrate addition. Reactions were considered positive when the absorbance value was three times as high as that of the corresponding control.

Total RNA was extracted from infected leaf tissues (SP 18 and MG 1669) by TRIZOL method, following the manufacturer's instructions. A pair of primers: CarMV-F (CAACACA TTTCAAT AAGTA CACCAA) and CarMV-R(CGTGYGTGT CTAACAAA CTTTTCT) were designed to amplify a fragment corresponding to the coat protein (CP) gene of CarMV. RT was performed in a reaction mixture (20 $\mu \mathrm{L})$ containing $5 \mathrm{X}$ RT buffer, dNTP (10 $\mathrm{mM})$, reverse primer $(25 \mathrm{mM})$, M-MLV Reverse transcriptase, milli Q water and $7 \mu \mathrm{L}$ of total RNA at $42^{\circ} \mathrm{C}$ for $1 \mathrm{~h}$. PCR was performed in $5 \mu \mathrm{L}$ of the synthesized cDNA, 5X PCR buffer, $\mathrm{MgCl} 2$, dNTPs (1,25 mM), DNA Taq polymerase and $1 \mu \mathrm{M}$ of forward and reverse primers. Conditions for PCR were as follows: $94^{\circ} \mathrm{C}$ for $3 \mathrm{~min}$ and 35 cycles of $94^{\circ} \mathrm{C}$ for $1 \mathrm{~min}, 54^{\circ} \mathrm{C}$ for 1 min, $72^{\circ} \mathrm{C}$ for $2 \mathrm{~min}$, followed by $10 \mathrm{~min}$ at $72^{\circ} \mathrm{C}$, performed on a thermal cycler.

The amplified PCR products were subject to electrophoresis in a $1.5 \%$ agarose gels containing ethidium bromide and were visualized using a UV transilluminator, purified with CONCERT Gel Extraction System (GIBCO-BLR, UK), concentrated, and sequenced in both forward and reverse directions, using an automated DNA sequencer (ABI PRISM 377 Sequencer, Applied Biosystems, USA).

The putative virus sequences were edited manually and pairwise identities were calculated after alignment of nucleotide (nt) and amino acid (aa) sequences by the program PAUP version 4.0b10 for Macintosh (Swofford, 2002). The program was also used for phylogenetic analysis by maximum parsimony (MP) and maximum likelihood (ML) methods. ML analysis was performed after determining the nucleotide substitution model, the proportion of invariable sites (I) and the gamma distribution (G) by likelihood ratio test (Huelsenbeck \& Rannala, 1997) in Modeltest version 3.06 (Posada \& Crandall, 1998) using star decomposition, TBR swapping algorithms.

\section{RESULTS AND DISCUSSION}

The CarMV isolated from carnation samples was mechanically transmitted to C. amaranticolor and C. quinoa inducing local lesions, as expected (Hollings $\&$ Stone, 1970), although under more extreme conditions $\left(35-40^{\circ} \mathrm{C}\right.$ day/10$15^{\circ} \mathrm{C}$ night), they were systemically infected developing chlorotic lesions on upper, non-inoculated $C$. quinoa leaves (García-Castillo et al., (2001).

Back-inoculation of SP-18 and MG1669 isolates was performed to Dianthus caryophyllus and D. chinensis which displayed latent infection with positive recovery on $C$. quinoa. On the other hand, D. barbatus "sweet william" was insusceptible, confirming the results of Stone (1968) who reported that CarMV is widely distributed in commercial carnation crops but is not recorded as being common in D. barbatus.

Carnation is the natural host for CarMV that generally induces mild or asymptomatic infection. However, in Taiwan, CarMV has been reported naturally infecting other ornamental plants such as Phalaenopsis sp. (orchid), Eustoma sp. (lisianthus) and Zanthedeschia sp. (calla lilies) (Chen et al., 2003, 2011; Zheng et al., 2011). These plants showed obvious foliar symptoms like chlorotic rings on orchid, systemic necrotic spot on lisianthus and yellow mottling, light yellow spot, yellow ringspot, and mosaic on fieldgrown calla lilies.

Serological tests (Table 1) revealed that six samples reacted positively to CarMV with absorbance values 8-13 times greater than negative control, and only sample 19 showed negative results. Moreover, three symptomless samples also reacted positively with the antiserum indicating that plants can accumulate high concentrations of virus without producing symptoms as observed for SP-14, SP-16 and SP-17 isolates. According to Lisa (1995), carnation infected with CarMV may not display symptoms, but decreases the quantity and quality of flowers.

In Brazil, CarMV was once reported in carnation from commercial production in Atibaia, Holambra and Paranapanema, 
Table 1. Serological test (DAS-ELISA) with Carnation mottle virus antiserum and carnation samples from different regions of São Paulo (SP) and Minas Gerais (MG) states \{teste sorológico (DAS-ELISA) com antissoro contra o Carnation mottle virus e amostras de craveiro dos estados de São Paulo (SP) e Minas Gerais (MG)\}. São Paulo, Instituto Biológico, 2012.

\begin{tabular}{lcc}
\hline Sample & Symptoms & Absorbance (405) \\
\hline SP 14 & Symptomless & 0.763 \\
SP 15 & Chorotic mottle & 0.711 \\
SP 16 & Symptomless & 0.671 \\
SP 17 & Symptomless & 0.654 \\
SP 18 & Mild mottle & $\mathbf{1 . 0 7 3}$ \\
SP 19 & Mild spots & 0.102 \\
MG 1669 & Chorotic and necrotic spots & $\mathbf{0 . 8 9 8}$ \\
\hline Positive control & & 0.627 \\
Negative control & & 0.081 \\
\hline
\end{tabular}

Table 2. Identity percentages between the nucleotide (nt) and amino acid (aa) sequences of two Carnation mottle virus (CarMV) Brazilian isolates and of 16 CarMV sequences available in GenBank \{porcentagens de identidade de sequências de nucleotídeos (nt) e aminoácidos (aa) de dois isolados brasileiros do Carnation mottle virus (CarMV) e outros 16 disponíveis no GenBank\}. São Paulo, Instituto Biológico, 2012.

\begin{tabular}{|c|c|c|c|c|}
\hline \multirow{2}{*}{ Acession $n^{\%} /$ country } & \multicolumn{2}{|c|}{ SP 18 JX 207140} & \multicolumn{2}{|c|}{ MG 1669 JX 207141} \\
\hline & nt & aa & nt & aa \\
\hline EF 622209/ Italy & 96.2 & 98.8 & 96.2 & 98.5 \\
\hline AJ 309499/ Italy & 98.8 & 99.4 & 99.0 & 99.1 \\
\hline EF 622211/ The Netherlands & 97.9 & 98.5 & 98.0 & 98.2 \\
\hline AJ309496/ The Netherlands & 98.8 & 99.4 & 98.8 & 99.1 \\
\hline AJ 304989/ Spain & 98.1 & 98.5 & 98.1 & 98.2 \\
\hline AJ 309511/ EUA & 99.1 & 98.5 & 98.7 & 98.2 \\
\hline AJ 811998/India & 98.1 & 98.5 & 98.1 & 98.2 \\
\hline AJ 844552/ India & 98.2 & 98.2 & 97.9 & 99.8 \\
\hline DQ 092486/ Iran & 97.8 & 99.7 & 97.9 & 99.4 \\
\hline AJ 309501/ Israel & 97.9 & 98.2 & 98.1 & 98.0 \\
\hline HQ 660513/ China & 99.0 & 99.4 & 98.7 & 99.1 \\
\hline AF 173879/ China & 98.1 & 98.5 & 98.2 & 98.2 \\
\hline HQ 704790/ China & 98.0 & 97.9 & 98.1 & 99.7 \\
\hline HQ 117872/ Taiwan** & 97.5 & 98.2 & 97.8 & 98.0 \\
\hline HQ 117870/ Taiwan* & 96.9 & 96.1 & 96.9 & 96.2 \\
\hline FJ843021/ Taiwan*** & 97.6 & 98.2 & 97.6 & 98.0 \\
\hline JX207140/ Brazil & - & - & 99.0 & 99.1 \\
\hline JX207141/ Brazil & 99.0 & 99.1 & - & - \\
\hline
\end{tabular}

*Zantedeschia $\mathrm{sp} .,{ }^{* *}$ Phalaenopsis sp., ${ }^{* * *}$ Eustoma sp.

São Paulo state (Caldari Junior et al., 1997). The authors identified the virus by serological test (Indirect-ELISA) and electron microscopic observations. However, sequences of the Brazilian CarMV have not been so far performed. Thus, two positive samples (SP-18 and MG-1669) that showed higher absorbance at $405 \mathrm{~nm}$ in serological test were subjected to total RNA extraction, only two changes Pro/Leu and Ser/Leu at positions 61 and 260, respectively. Canizares et al. (2001) identified two distinct strain groups of CarMV, denoted PK and AN, based on the co-variation between aa at position 164, located in the $\mathrm{S}$ domain and at position 331, located in the P domain. The sequences of Brazilian isolates showed within the structural domains $\mathrm{S}$ and $\mathrm{P}$, Pro and Lys aa, respectively, indicating that they belong to the group PK.

Comparisons among nucleotide sequences of Brazilian isolates showed similar identity ranging from $96 \%$ to $99 \%$ compared with carnation isolates from other countries (Table 2). Similar results were observed when sequences were compared with CarMV isolated from lisianthus (FJ843021), orchid (HG117872) and calla lilies (HQ117870).

The pattern of nt substitution was $\mathrm{HKY}+\mathrm{I}+\mathrm{G}$, where $\mathrm{I}=0.6408$ and $\mathrm{G}=0.8720$. Phylogenetic analyses (maximum parsimony and maximum likelihood) were conducted and the tree topologies were similar. Brazilian isolates of CarMV do not show a tendency to group by geographic region, once they fell in paraphyletic groups in the phylogenetic tree reconstructed under MV condition (Figure 1). Despite low variability among CarMV isolates, regardless of the geographic region and host origin, it was found that SP isolate shares a common ancestor with Indian isolate, while $\mathrm{MG}$ isolate with isolates from Italy and The Netherlands.

CarMV presents a high genetic stability not easy to explain (Cañizares et al., 2001). A possible hypothesis would be to consider the negative selection to variation that would limit the variable sites in the genome of a carmovirus, among the smallest plant viruses known so far. Host-associated selection has been described as a factor of pressure that could result in a decrease of diversity within a viral population. However, this seems not to be the case, since CarMV isolates characterized from wild plants show nucleotide sequences almost identical to those described by Cañizares et al. (2001).

CarMV has a very wide geographical distribution which is probably co- 


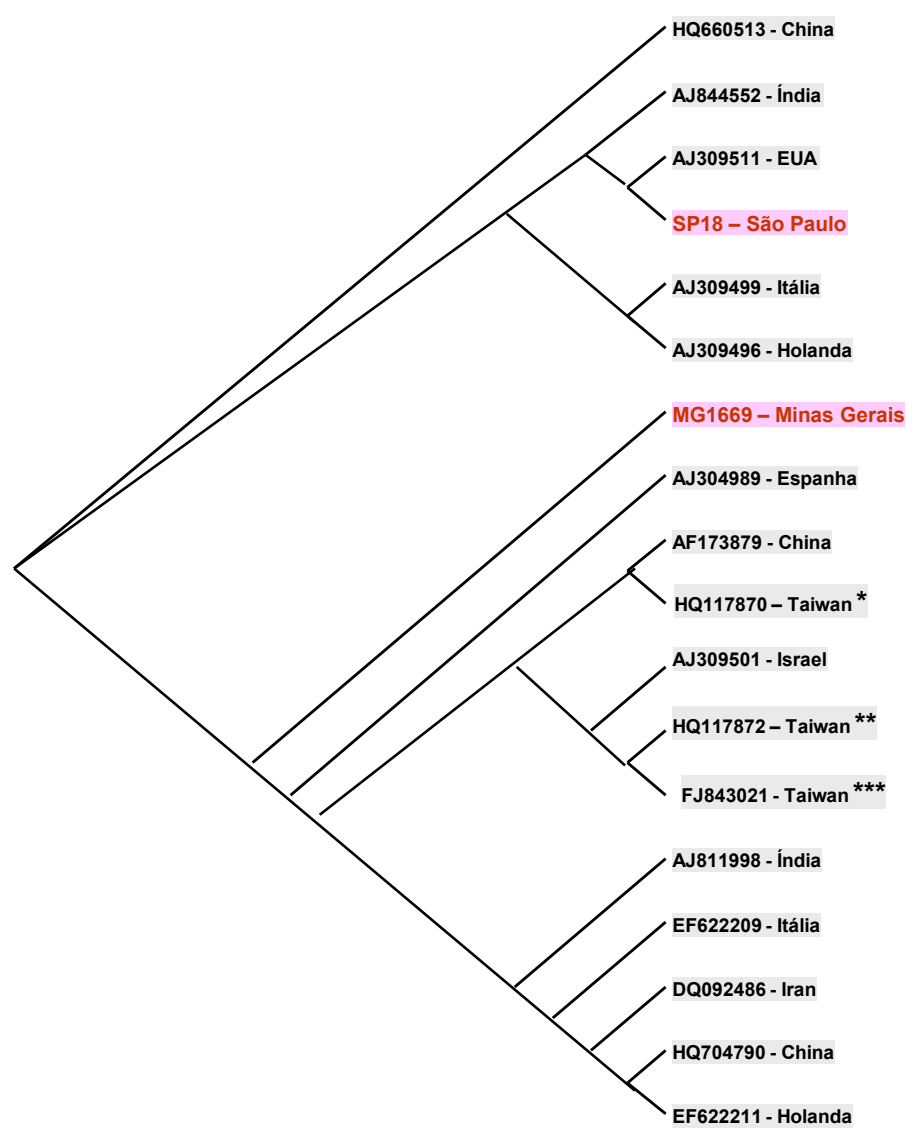

Figure 1. Phylogenetic tree constructed with coat protein nucleotide sequences of Carnation mottle virus isolates from two geographic regions of Brazil and those available in GenBank. SP18 (JX207140), MG1669 (JX207141) \{árvore filogenética construída com as sequências da capa proteica de isolados de Carnation mottle virus de dois estados brasileiros e as disponíveis no GenBank. SP18 (JX207140), MG1669 (JX207141) ; highlighted sequences = Brazilian isolates (sequências em destaque $=$ isolados brasileiros); ${ }^{*}$ Zantedeschia $\mathrm{sp}$. , **Phalaenopsis sp., ***Eustoma sp. São Paulo, Instituto Biológico, 2012.

incident with the commercial cultivation of carnations and pinks. This extensive distribution is probably due to inadvertent international exchange of infected plantlets and germplasm before the virus had been identified (Brunt \& Martelli, 2008). The virus is considered to be invasive because it is stable in vitro and highly infectious, it is readily transmitted mechanically from infected to healthy plants. Thus, as visual inspections are not a reliable indication for recognizing carnation viruses, careful diagnosis for early detection by serological and/or molecular assays are fundamental, so that virus spread can be greatly reduced by the application of sanitary precautions. This is the first report of CarMV from Minas Gerais, of $\mathrm{CP}$ nucleotide sequences from Brazilian
CarMV isolates, as well as molecular phylogenetic analyses in Brazil.

\section{REFERENCES}

BRUNT AA; MARTELLI GP. 2008. Carnation mottle virus. C.M.I./A.A.B. Descriptions of Plant Viruses 420p.

CALDARI JRP; FREITAS JC; REZENDE JAM; KITAJIMA EW. 1997. Ocorrência do "Carnation mottle virus" em craveiro no Estado de São Paulo. Fitopatologia Brasileira 22: 451.

CAÑIZARES MC, MARCOS JF; PALLÁS V. 2001. Molecular variability of twenty-one geographically distinct isolates of Carnation mottle virus (CarMV) and phylogenetic relationships within the Tombusviridae family. Archives of Virology 146: 2039-2051.

CEVIK B; BAKIR T; KOCA G. 2010. First report of Carnation mottle virus in Turkey. Plant Pathology 59: 394.
CHEN CC; KO WF; LIN CY; JAN FJ; HSU HT. 2003. First report of Carnation mottle virus in Calla lily (Zantedeschia spp.). Plant Disease 87: 1539.

CHEN YK; CHANG YS; CHEN CC. 2011. Identification of Carnation mottle virus from Lisianthus plants in Taiwan. Plant Disease 95: 1036.

CLARK MJ; ADAMS AN. 1977. Characteristics of the microplate method of enzyme-linked immunosorbent assay for the detection of plant viruses. Journal General Virology 34: 574-586.

GARCÍA-CASTILLO S; MARCOS JF; PALLÁS V; SANCHEZ-PINAF MA. 2001. Influence of plant growing conditions on the translocation routes and systemic infection of Carnation mottle virus in Chenopodium quinoa plants. Physiological and Molecular Plant Pathology 58: 229-238.

HOLLINGS M; STONE OM. 1970. Carnation mottle virus. C.M.I./ A.A.B. Descriptions of Plant Viruses $\mathrm{n}^{\circ} 7$.

HUELSENBECK JP; Rannala B. 1997. Phylogenetics methods come of age: testing hypotheses in an evolutionary context. Science 276: 227-232.

ICTV. 2013. Carmovirus. In: International Committee on Taxonomy of Viruses: 2012 release. http://www.ictvonline.org/ virusTaxonomy. Accessed 12 March 2014.

JUNQUEIRAAH; PEETZ MS. 2002. Os pólos de produção de flores e plantas ornamentais do Brasil: uma análise do potencial exportador. Revista Brasileira de Horticultura Ornamental 18: 25-47.

LANDGRAF PRC; PAIVA PDO. 2009. Produção de flores cortadas no estado de Minas Gerais. Ciência e Agrotecnologia 33: 120-126.

LISA V. 1995. Carnation. In: LOEBENSTEIN G; LAWSON RH; BRUNT AA (eds). Virus and virus-like diseases of bulb and flowers crops. Chichester: John Wiley \& Sons. p.385-395.

POSADA D; CRANDALL KA. 1998. Modeltest: testing the model of DNA substitution. Bioinformatics 14: 817-818.

QU F; MORRIS TJ. 2008. Carmovirus. In: MAHY BWJ; REGENMORTEL MHV (eds) Encyclopedia of Virology, Academic Press. p.453-457.

SAFARI M; KOOHI HM; MOSAHEBI G; DIZADJI A. 2009. Carnation mottle virus, an important viral agent infecting carnation cutflower crops in Mahallat of Iran. Communicate Agricultural Applied Biological Science 74: 861-865.

SOUZA MALB; SIMÃO S. 1981. Efeitos da densidade de plantio sobre a qualidade de cravos, Dianthus caryophyllus Anais da ESALQ. XXXVIII, 623-641.

STONE OM. 1968. The elimination of four viruses from carnation and sweet William by meristem-tip culture. The Annals of Applied Biology 62: 119-122.

SWOFFORD DL. 2002. PAUP*: Phylogenetic analysis using parsimony (*and related methods). Version 4.0b10. Massachusetts: Sinauer Associates.

ZHENG YX; CHEN CC; JAN FJ. 2011. First report of Carnation mottle virus in Phalaenopsis orchids. European Journal Plant Pathology 95: 354. 